\title{
UPAYA GURU AL-QUR'AN DALAM MENGATASI KESULITAN BELAJAR MEMBACA AL-QUR'AN DI SDIT UKHUWAH BANJARMASIN
}

\author{
Hafiz Mubarak
}

Fakultas Tarbiyah dan Keguruan

IAIN Antasari Banjarmasin

\begin{abstract}
This research had goal to gain knowledge about any difficulties experienced by student since learning to read the Quran and what methods used by the Quran teachers to overcome learning difficulties. This research used qualitative approach. The amount of data source was not determined, but it was based on snowball sampling. Although, the amount of research subject was not determined, the process of moving the research data was on subjects at SDIT "Ukhuwah" Banjarmasin. The results showed that the learning difficulties experienced by students in the third grade to learn to read the Qur'an were: the students were difficult to concentrate or to focuse; a very active student verbally; slow student learning; student who had a low voice; student shard looked; students actively engaged; passive student; students had not been studied together with the child standard abilities; the number of children who were too much in the group.
\end{abstract}

Kata kunci: upaya guru, kesulitan belajar, membaca al-Quran

\section{Pendahuluan}

Pembelajaran Al-Qur'an yang optimal akan melahirkan generasi Qur'ani yang mampu memakmurkan bumi dengan Al-Qur'an dan menyelamatkan peradaban dunia di masa mendatang. ${ }^{1}$ Syarat mutlak untuk memunculkan generasi Qur'ani adalah adanya pemahaman terhadap Al-Qur'an yang diawali dengan mampu membaca Al-Qur'an dengan baik dan benar sesuai dengan kaidah yang telah ditentukan.

Langkah awal untuk mencapai hal tersebut adalah umat Islam harus mampu membaca huruf-huruf Al-Qur'an. Kemampuan membaca Al-Qur'an tidak dapat dipisahkan dari kegiatan pembelajaran Al-Qur'an. Oleh karena itu, dalam Islam pembelajaran Al-Qur'an merupakan suatu kewajiban yang suci dan mulia. Secara spesifik, Rasulullah saw. menegaskan kewajiban mendidik Al-Qur'an dalam hadisnya:

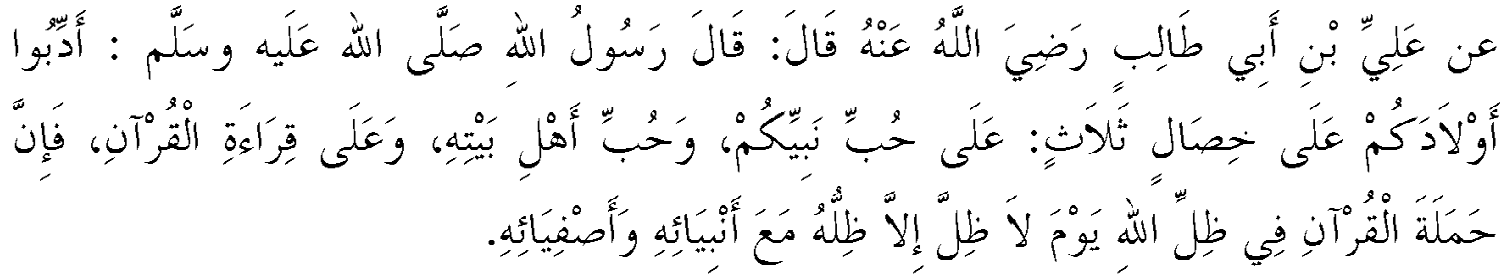

${ }^{1}$ Hayatun Fardah Rudi Arifin, Belajar Al-Qur'an Strategis Siapkan Generasi Qur'ani, (http://www.depag.go.id., diakses 10 April 2013). 
Artinya: Dari Ali bin Abi Thalib r.a. berkata: Rasulullah saw. bersabda: "Didiklah anakmu dengan tiga perkara, yaitu mencintai Nabimu, mencintai keluarga Nabi, dan membaca Al-Qur'an, sesunggubnya orang yang berpegang teguh pada Al-Qur'an berada pada perlindungan Allah swt pada bari tidak ada perlindungan kecuali lindungan-Nya bersama-sama dengan Nabi-nabi dan Sababat-sahabatnya yang tulus" (H.R. Ad-Daylami 'an 'Tliyyi). ${ }^{2}$

Hadis tersebut menjelaskan bahwa diantara pendidikan dasar yang harus diberikan kepada anak adalah membaca Al-Qur'an. ${ }^{3}$

Mengingat pentingnya pembelajaran Al-Qur'an, Rasulullah saw. menganjurkan pembelajaran membaca Al-Qur'an dimulai sejak masa kanak-kanak karena pada masa itu terkandung potensi belajar yang sangat kuat dan besar. Anak akan sangat peka menangkap sesuatu yang diperintahkan dan diajarkan sehingga mudah menerima pelajaran-pelajaran yang diberikan. Namun masalahnya, Al-Qur'an disampaikan dalam bahasa Arab dan tidak semua umat muslim di Indonesia menguasai bahasa tersebut. Belajar membaca Al-Qur'an artinya belajar mengucapkan lambang-lambang bunyi (huruf) tertulis. Walaupun kegiatan ini cukup sederhana, tetapi bagi siswa pemula merupakan kegiatan yang cukup kompleks, karena harus melibatkan berbagai hal, yaitu penglihatan, pendengaran, pengucapan disamping akal pikiran. Kedua hal terakhir ini bekerja secara mekanik dan simultan untuk melahirkan perilaku membaca. Ditambah lagi materi yang dibaca adalah rangkaian kata-kata Arab yang banyak berbeda sistem bunyi dan penulisannya dengan yang mereka kenal dalam bahasa ibu dan bahasa Indonesia. ${ }^{4}$

Apalagi pemandangan yang cukup memprihatinkan adalah akhir-akhir ini dirasakan kecintaan membaca Al-Qur'an di kalangan umat Islam sendiri agak semakin menurun. Budaya membaca Al-Qur'an di rumah-rumah setelah shalat fardhu sudah jarang didengarkan. Membaca Al-Qur'an telah digantikan dengan bacaan-bacaan atau media-media informasi lain seperti: koran atau surat kabar, majalah, televisi dan lain-lain, padahal mereka tahu membaca Al-Qur'an merupakan ibadah yang memperoleh pahala dari Allah SWT. Jika umat Islam sudah merasa tidak penting untuk membaca Al-Qur'an, maka siapakah yang akan mau membaca Al Qur'an kalau bukan orang Islam itu sendiri. ${ }^{5}$

Dalam hal ini, proses belajar mengajar sangat penting untuk meningkatkan kualitas anak dalam membaca Al-Qur'an. Dan dalam proses pembelajaran upaya atau usaha guru sangatlah penting demi kelangsungan proses belajar mengajar yang baik. Dalam pengertian upaya atau usaha mempunyai arti yang sama yaitu ikhtiar untuk mencapai sesuatu yang hendak dicapai. Sedangkan pengertian guru itu sendiri adalah pendidik profesional, karena ia telah merelakan dirinya menerima dan memikul sebagian tanggungjawab pendidikan yang sebenarnya menjadi tanggungjawab orang tua. ${ }^{6}$

${ }^{2}$ As-Suyuthi, Jam'ul Jawami' aw al-Jami'ul Kabir, (tp.), bab huruf hamzah, juz 1, hadits ke-924, h. 1251.

${ }^{3}$ Ahmad Syarifuddin, Mendidik. Anak Membaca, Menulis, dan Mencintai Al-Qur'an (Jakarta: Gema Insani Press, 2004), h. 28 .

${ }^{4}$ Depag RI, Metode-metode Membaca Al-Qur'an di Sekolah Umum (Jakarta: Dirjen Pembinaan Kelembagaan Agama Islam, 1997), h. 24.

${ }^{5}$ Abu Yahya As-Syilasyabi, Cara Mudah Membaca Al-Qur'an Sesuai Kaidah Tajwid (Yogyakarta: Daar Ibn Hazm, 2007), h. 13.

${ }^{6}$ Zakiah Daradjat, Ilmu Pendidikan Islam (Jakarta: Bumi Aksara, 1996), h. 39. 
Faktor guru mempunyai pengaruh terhadap kualitas pengajaran. Guru yang mempunyai kemampuan dasar, baik bidang kognitif (intelektual) seperti penguasaan bahan, keteladanan, sikap mencintai profesinya dan bidang perilaku seperti keterampilan mengajar, menilai hasil belajar dan lain-lain akan menghasilkan kualitas pengajaran yang baik. Selain itu juga, faktor siswa dan faktor lingkungan ${ }^{7}$ juga mempengaruhi kualitas pembelajaran. Siswa yang mempunyai kemampuan yang tinggi, motivasi, minat, perhatian belajar yang kuat dan kebiasaan belajar dan beribadah yang rajin serta didukung dengan suasana belajar yang demokratis, tenang, kondusif dan fasilitas dan sumber belajar yang tersedia akan menghasilkan kualitas pembelajaran yang lebih baik lagi.

Dari hasil observasi awal di SDIT Ukhuwah Banjarmasin penulis temukan bahwa proses pembelajaran Al-Qur'an khususnya di kelas III ruang belajarnya yang kurang kondusif, karena sistem pengajaran Al-Qur'annya menggunakan kelompok dalam satu kelas yang terdiri dari kurang lebih 10-15 siswa dalam satu kelompok, sehingga ruang kelas yang ada tidak mencukupi. Terpaksa sebagian kelompok ada yang belajar di dalam masjid dan sebagian yang lain belajar di tempat terbuka seperti di teras masjid dan di kantin. Selain itu, karena kelompok yang satu berdekatan dengan kelompok yang lain sehingga tercampur suara anak satu yang lain, ditambah lagi ada sebagian anak yang berteriak (bersuara terlalu keras). ${ }^{8}$

Padahal menurut Rosenshine dan Steven, salah satu konsep paling penting yang telah dikembangkan dalam psikologi pendidikan selama 30 tahun terakhir adalah bahwa variabel proses ruang kelas mempunyai hubungan yang paling langsung dengan prestasi siswa. ${ }^{9}$ Secara lebih spesifik, perilaku ruang kelas guru mempunyai pengaruh langsung terhadap perilaku siswa (yang paling penting adalah waktu pembelajaran akademis), yang pada gilirannya berkaitan secara langsung dengan ukuran prestasi siswa.

Selain faktor ruang belajar, juga faktor siswa yaitu tidak semua siswa memiliki kemampuan pemahaman baca Al-Qur'an yang sama dan input siswa yang beragam terkadang ada siswa dari sekolah lain yang pindah ke SDIT Ukhuwah tersebut yang mana kualitas pembelajarannya beda. Sedangkan dari faktor lainnya yaitu terbatasnya waktu dan kurangnya dorongan dari orang tua murid. ${ }^{10}$

Dari faktor-faktor itulah yang menimbulkan kesulitan-kesulitan belajar yang dialami oleh siswa di sekolah. Dan disebabkan kesulitan-kesulitan itu yang akan mempengaruhi siswa dalam meningkatkan kemampuan baca Al-Qur'an.

Untuk mengatasi hal tersebut, perlu adanya upaya-upaya dari berbagai pihak. Salah satunya yang sangat penting adalah upaya dari guru Al-Qur'an sendiri bagaimana cara mengajarkan Al-Qur'an yang efektif sehingga anak dengan mudah memahami apa yang disampaikan guru. Untuk itulah bagaimana guru menentukan metode dan pendekatan yang tepat sehingga para siswa mampu meraih hasil belajar yang optimal dan mencapai target yang dicanangkan pihak

${ }^{7}$ Ahmad Munjin Nasih dan Lilik Nur Kholidah, Metode dan Teknik Pembelajaran Pendidikan Agama Islam (Bandung: Refika Aditama, 2009), h. 24.

${ }^{8}$ Observasi awal di SDIT Ukhuwah Banjarmasin, tanggal 18 Maret 2013.

${ }^{9}$ Dina Indriana, Mengenal Ragam Gaya Pembelajaran Efektif (Jogjakarta: DIVA Press, 2011), h. 62.

${ }^{10}$ Wawancara dengan Bapak Fahrudi dan Ustadzah Sri Hartini, guru Al-Qur'an di SDIT Ukhuwah Banjarmasin, tanggal 18 Maret 2013. 
kurikulum. ${ }^{11}$ Walaupun setiap metode pembelajaran di dalamnya terdapat kelebihan dan kekurangan, tapi bagi seorang guru kecermatan dalam memilih metode yang sesuai dengan situasi dan kondisi anak didik menjadi sangat penting. Misalnya ketika mengajarkan bacaan AlQur'an, guru Al-Qur'an hendaknya memilih metode yang memungkinkannya dapat memberi contoh sebanyak mungkin kepada anak didik, dan bukan hanya ceramah dengan menjelaskan beragam teori seputar ilmu tajwid.

Hal yang menarik dalam pembelajaran membaca Al-Qur'an di SDIT Ukhuwah Banjarmasin adalah guru atau ustadz yang mengajar Al-Qur'an harus ditashbîh (dites) bacaannya terlebih dahulu. Pentashihan ini merupakan tahap awal bagi seseorang yang ingin mengajarkan Al-Qur'an di sekolah tersebut. Tashbîh bertujuan untuk mengetahui kompetensi ustadz atau ustadzah yang akan mengajar Al-Qur'an. Dan guru Al-Qur'an tersebut harus mengikuti pelatihan dan sertifikasi untuk mengetahui bagaimana cara mengajarkan membaca Al-Qur'an kepada siswa. ${ }^{12} \mathrm{Jadi}$ semua guru yang ada di SDIT Ukhuwah Banjarmasin sudah mendapatkan pelatihan dan sertifikasi tersebut. Di sinilah nantinya guru yang profesional berperan dalam mengatasi kesulitan-kesulitan yang dialami siswa dalam belajar membaca Al-Qur'an.

\section{Metode Penelitian}

Penelitian ini adalah penelitian lapangan (field research). Yaitu dilakukan dalam kancah kehidupan yang sebenarnya, yakni di SDIT Ukhuwah Banjarmasin. Penelitian yang digunakan adalah penelitian kualitatif yaitu penelitian yang ditujukan untuk mendeskripsikan dan menganalisis fenomena, peristiwa, aktifitas pembelajaran Al-Qur'an di SDIT Ukhuwah tersebut.

Dalam penelitian kualitatif ini data yang dikumpulkan dari hasil wawancara, catatan lapangan, dokumen pribadi seperti yang dikatakan oleh Bogdan dan Taylor mendefinisikan bahwa, metode kualitatif yaitu sebagai prosedur penelitian yang menghasilkan data deskriptif berupa kata-kata tertulis atau lisan dari orang-orang atau perilaku yang diamati. ${ }^{13}$

Sumber data dalam penelitian ini adalah subyek dari mana data diperoleh. Apabila peneliti menggunakan kuesioner/wawancara dalam pengumpulan datanya, maka sumber data tersebut responden, yaitu orang-orang yang merespon atau menjawab pertanyaan peneliti, baik pertanyaan tertulis atau lisan dan apabila peneliti menggunakan teknik observasi, maka sumber datanya bisa berupa benda, gerak atau proses sesuatu, serta apabila peneliti menggunakan dokumentasi, maka dokumentasi atau catatanlah yang menjadi sumber data. Sedang isi catatan sebagai subjek penelitian atau variabel penelitian. ${ }^{14}$

Dalam pengumpulan data, penulis menggunakan teknik atau metode sebagai berikut:

Metode Observasi adalah pengumpulan data yang dilakukan dengan cara mengamati dan mencatat secara sistematis gejala-gejala yang diselidiki. ${ }^{15}$ Metode ini digunakan untuk memperoleh data yang berkaitan dengan geografis, keadaan serta proses belajar mengajar.

\footnotetext{
${ }^{11}$ Harun Maidir, dkk.,Kemampuan Baca Tulis Al-Qur'an Siswa SMA Jakarta: DEPAG badan Litbang dan Puslitbang, 2007), h. 10.

${ }^{12}$ Wawancara dengan Bapak Syaiful Mukmin, Kepala Sekolah SDIT Ukhuwwah Banjarmasin, tanggal 20 Maret 2013.

${ }^{13}$ Lexy J. Moleong, Metodologi Penelitian Kualitatif (Bandung: Rosda Karya, 2002), h. 3.

${ }^{14}$ Lihat Suharsimi Arikunto, Prosedur penelitian suatu pendekatan praktik (Jakarta: Rineka Putra, 2006), h. 155.

${ }^{15}$ Lihat Cholid Narbuko dan Abu Ahmadi, Metodologi Penelitian (Jakarta: Bumi Aksara, 2005), h. 70.
} 
Metode wawancara (interview) adalah proses tanya-jawab dalam penelitian yang berlangsung secara lisan dalam dua orang atau lebih, bertatap muka dan mendengarkan secara langsung informasi-informasi yang diberikan. Bentuk interview yang digunakan penulis dalam penelitian ini adalah interview bebas dan terpimpin dapat juga disebut dengan interview tercontrol atau controlled interview. Dalam interview bebas terpimpin ini penginterview sudah mempersiapkan pertanyaan-pertanyaan secara lengkap dan cermat. ${ }^{16}$ Wawancara ini ditujukan kepada Kepala Sekolah, guru-guru Al-Qur'an dan murid.

Metode Dokumentasi yaitu mencari hal-hal atau variabel yang berupa catatan, transkrip, buku, surat kabar, majalah, agenda dan sebagainya. Metode ini digunakan untuk memperoleh profil sekolah, keadaan guru dan siswa dan struktur sekolah di SDIT tersebut.

Untuk analisis data Moleong mengatakan analisis data kualitatif adalah upaya yang dilakukan dengan jalan bekerja dengan data, memilah-milah menjadi satuan yang dapat dikelola, mensintesiskannya, mencari dan menemukan apa yang penting dan apa yang dipelajari, dan menemukan apa yang dapat diceritakan pada orang lain.

Data yang diperoleh melalui wawancara, dokumentasi dan observasi itu kemudian dituangkan ke dalam bentuk uraian yang disusun sesuai dengan kerangka sistematika penulisan yang telah ditentukan dan disertai analisis. Dengan demikian, penulisan ini bersifat analisis deskriptif (deskriptive analysis).

Sementara untuk mendapatkan kesimpulan dipergunakan teknik induktif, yaitu dari bermacam variabel (hal-hal yang bersifat khusus) untuk ditarik menjadi hal-hal yang bersifat umum. Pengolahan data dilakukan setelah data terkumpul, terlebih dahulu dilakukan editing terhadap data yang ada, apakah sudah mencukupi atau masih diperlukan perbaikan, penyempurnaan dan penyelarasan lebih jauh.Tahap berikutnya melakukan klasifikasi terhadap data yang terkumpul, untuk kemudian dilakukan interpretasi. Data diolah sedemikian rupa dalam bentuk deskriptif kualitatif.

\section{Hasil Penelitian}

Berdasarkan dari pemaparan hasil wawancara dan pengamatan penulis dapat diketahui kesulitan-kesulitan belajar membaca Al-Qur'an di SDIT Ukhuwah Banjarmasin khususnya pada siswa kelas III adalah sebagai berikut:

a. Siswa sulit konsentrasi atau memusatkan perhatian

Siswa pasif pada saat klasikal baca simak. Biasanya sibuk memegang sesuatu atau pandangan kabur dan tertuju ke sesuatu yang menarik perhatiannya selain alat peraga atau buku.

b. Siswa sangat aktif secara verbal

Siswa lebih suka bercakap-cakap dengan teman, jika ikut membaca dengan suara yang keras atau berteriak.

c. Siswa lambat belajar

Siswa lambat untuk memahami konsep yang dipelajari pada halaman-halaman tertentu. Kesulitan ini akan bertumpuk jika membaca kalimat yang secara konseptual kompleks dan panjang.

\footnotetext{
${ }^{16}$ Lihat Sutrisno Hadi, Metodologi Reseach Jilid 2 (Jogyakarta: Andi Offset, 2004), h. 233.
} 
d. Siswa dengan suara pelan

Siswa membaca dengan suara pelan, bahkan hanya bibirnya saja yang bergerak tanpa mengeluarkan suara. Kemungkinan siswa kurang percaya diri, atau belum terlatih untuk menggunakan kemampuan verbalnya. Tapi terkadang suara guru juga tidak terdengar jelas oleh siswa.

e. Siswa susah melihat

Ada siswa yang susah melihat mungkin karena alat peraganya jauh sehingga tulisannya tidak terlalu jelas atau mata anak yang kurang jelas.

f. Siswa aktif bergerak

Siswa bergeser tempat duduk, memainkan perlengkapan, bahkan mengunjungi kelompok lain.

g. Siswa fasif

Melamun, pandangan kabur, lengah, berdiam diri, dan menunjukkan ketidaktertarikan.

h. Siswa yang kemampuannya rendah sulit belajar bersama dengan anak yang kemampuannya standar atau di atas rata-rata.

Adapun metode yang digunakan guru Al-Qur'an untuk mengatasi kesulitan belajar siswa tersebut dengan metode Ummi di mana di dalam metode tersebut memiliki variasi metode sebagai berikut:

1. Membuat kelompok sesuai kemampuan dan tingkat siswa

2. Menggunakan buku dan alat peraga pada saat klasikal

3. Pengulangan dan muraja'ah

4. Pelibatan siswa

Guru meminta salah satu siswa untuk maju ke depan dan menunjuk tulisan pada alat peraga pada saat klasikal dengan Teknik 1 (guru membaca siswa mendengar) dan Teknik 2 (guru mendengar siswa membaca). Pelibatan siswa ini dapat dilakukan secara bergantian terutama pada siswa yang cenderung moving atau banyak gerak.

5. Penggabungan metode klasikal baca simak atau klasikal baca simak murni

Penggabungan klasikal peraga dengan baca simak yaitu siswa membaca kalimat, siswa yang lain mendengarkan, kemudian jika ada kesalahan dikoreksi, lakukan pengulangan konsep secara singkat. Kemudian guru dan siswa membaca bersama-sama kalimat tersebut. Siswa kedua membaca kalimat berikutnya, siswa yang lain mendengarkan, kemudian guru dan siswa membaca bersama-sama kalimat tersebut, dan seterusnya sampai semua kalimat di halaman peraga terbaca.

6. Drill (latihan keterampilan)

Guru memberikan latihan kepada siswa setelah penanaman konsep dan contoh-contoh yan sudah ada di dalam buku. Siswa disuruh membacakan beberapa ayat dan guru mendengarkan serta menilai kualitas bacaan anak.

7. Mengatasi siswa yang memerlukan penanganan khusus

Siswa yang memerlukan pengangan khusus yaitu siswa yang kemampuannya di bawah standar atau siswa yang tidak mencapai target yang sudah ditentukan. Siswa tersebut akan dibedakan dengan siswa yang kemampuannya standar dan metode yang digunakan juga berbeda yaitu metode privat atau metode klasikal individual 


\section{Analisis}

\section{Kesulitan-kesulitan siswa kelas III dalam belajar membaca Al-Qur'an}

Dalam pelaksanaan pembelajaran terkadang timbul kesulitan-kesulitan belajar yang dialami siswa tidak terkecuali pembelajaran membaca Al-Qur'an. Dari hasil wawancara dengan kepala sekolah, bapak/ibu guru Al-Qur'an, dan beberapa siswa kelas III di SDIT Ukhuwah Banjarmasin peneliti dapat mengetahui kesulitan belajar siswa kelas III dalam membaca Al-Qur'an sebagai berikut:

a. Siswa sulit konsentrasi atau memusatkan perhatian

Belajar di tempat terbuka seperti di kantin, di teras mesjid membuat perhatian anak tidak fokus, apalagi ada kegiatan lain di luar kelas atau ada sesuatu pemandangan yang menarik siswa akan mudah bagi siswa perhatiannya teralih atau sulit konsentrasi pada saat pelajaran.

Perhatian merupakan keaktifan jiwa yang dipertinggi, jiwa itu pun semata-mata tertuju kepada suatu objek atau benda-benda atau sekumpulan objek. Supaya timbul perhatian siswa terhadap bahan pelajaran, usahakanlah bahan pelajaran selalu menarik perhatian dengan cara mengusahakan pelajaran itu sesuai hobi atau bakatnya.

b. Siswa sangat aktif secara verbal

Siswa lebih suka berbicara dengan temannya yang lain pada saat pelajaran, jika ikut membaca dengan suara yang keras atau berteriak.

Tiap orang mempunyai kebiasaan balajarnya sendiri-sendiri. Ada yang biasa belajar malam hari dan ada juga yang biasa belajar siang hari. Ada yang suka mencoret-coret bukunya dengan pulpen atau dengan tanda-tanda tertentu, tetapi ada juga yang lebih suka membuat catatan kecil dari keseluruhan isi buku, ada yang suka berteriak-teriak. Memang kebiasaan belajar ini bersifat individual, tak bisa ditentukan sama rata untuk setiap orang. Namun demikian tentu saja tak boleh terlalu terikat pada kebiasaan-kebiasaan itu, dan juga tidak boleh menganut kebiasaan belajar yang tidak teratur, tidak menentu. Akan tetapi setiap kali harus berusaha memperbaiki kebiasan belajar, sehingga pada akhirnya kita memiliki kebiasaan belajar yang baik, berencana, dan efesien. Terlalu terikat pada sesuatu kebiasaan saja, akan turut mengahambat proses pembelajaran.

c. Siswa lambat belajar

Di antara kesulitan belajar yang lain yaitu siswa lambat untuk memahami konsep yang dipelajari pada halaman-halaman tertentu. Seperti sulit membaca panjang pendek pada ayat, dengung, dan pengucapan makhraj huruf atau sulit membaca kalimat yang secara konseptual kompleks dan panjang. Biasanya anak seperti ini kemampuannya di bawah standar sehingga perlu ada penanganan khusus dari guru. Lambat ini kemungkinan timbul dari faktor kemampuannya atau intelegensinya. Karena intelegensi merupakan kecakapan yang terdiri atas tiga jenis, yaitu: (1) kecakapan untuk menghadapi dan menyesuaikan diri ke dalam situasi yang baru dengan cepat dan efektif, (2) mengetahui atau menggunakan konsep-konsep yang abstrak secara efektif, (3) mengetahui relasi dan mempelajarinya dengan cepat.

d. Siswa dengan suara pelan

Dengan suasana belajar yang tidak kondusif seperti keadaan yang ribut karena tercampurnya suara anak kelompok yang satu dengan suara anak kelompok yang lain disebabkan ada 
beberapa kelompok yang berdekatan dalam satu ruangan seperti di mesjid yangmana ruangannya tidak terlalu besar, begitu pula di kantin tempat yang terbuka sehingga ketika siswa membaca dengan suara pelan tidak kedengaran oleh guru, bahkan hanya bibirnya saja yang bergerak tanpa mengeluarkan suara. Dan juga terkadang suara guru tidak terdengar jelas oleh siswa. Anak yang suara pelan itu kemungkinan bisa disebabkan kerana kondisi lingkungan yang ribut, atau kurang terbiasa dengan suara keras, bisa juga karena kurang percaya diri terhadap penguasaan materi yang disampaikan.

e. Siswa susah melihat

Ada siswa yang susah melihat kemungkinan karena alat peraganya agak jauh sehingga tulisannya tidak terlalu jelas atau karena mata anak yang kurang jelas.

Kesehatan yang sering terganggu: badan yang sering sakit, kurangnya tenaga, kurang vitamin, mata yang tidak jelas merupakan faktor yang bisa menghambat kemajuan studi seseorang. Adanya gangguan emosional, rasa tak tenang, khawatir, mudah tersinggung, sikap agresip, gangguan-gangguan dalam proses berpikir, semuanya menjadikan kegiatan belajar terganggu. Faktor kesehatan jasmani dan rohani turut menentukan apakah studi seseorang akan lancar atau tidak. Hendaknya diusahakan agar kesehatan ini terus diperhatikan.

f. Siswa aktif bergerak

Kesulitan belajar yang lain adalah ada sebagian siswa yang aktif bergerak seperti bergeser tempat duduk, memainkan perlengkapan, berjalan-jalan, bahkan mengunjungi kelompok lain. Siswa seperti ini biasanya senang dengan gaya belajar kinestetik.

Sikap siswa merupakan gejala internal yang berdimensi afektif, berupa kecenderungan untuk mereaksi atau merespon dengan cara yang relatif tetap terhadap objek tertentu, seperti orang, barang, dan sebagainya, baik secara positif maupun negatif.

g. Siswa pasif

Sebagian siswa ada yang pasif seperti melamun, pandangan kabur, lengah, berdiam diri, dan menunjukkan ketidaktertarikan pada saat belajar membaca Al-Qur'an.

Minat sangat penting dalam keberhasilan seseorang. Minat merupakan kecenderungan yang tetap untuk memperhatikan dan mengenang beberapa kegiatan. Minat besar pengaruhnya terhadap belajar, karena apabila bahan pelajaran yang dipelajari tidak sesuai dengan minat siswa atau tidak diminati siswa, maka siswa yang bersangkutan tidak akan belajar sebaik-baiknya, karena tidak ada daya tarik baginya. Sebaliknya bahan pelajaran yang diminati siswa, akan lebih mudah dipahami dan disimpan dalam memori kognitif siswa karena minat dapat menambah kegiatan belajar. Oleh sebab itu, sangat penting sekali motivasi dari seorang guru untuk menumbuhkan minat, perhatian dan kemauan siswa dalam belajar.

h. Siswa yang kemampuannya rendah sulit belajar bersama dengan anak yang kemampuannya standar atau di atas rata-rata.

Kemampuan anak beragam, ada yang standar ada yang di bawah standar atau ada anak yang cepat pemahamannya ada juga yang lambat sehingga ketika anak digabung menjadi satu kelompok anak yang kemampuannya rendah tidak mampu mengikuti anak yang kemampuannya standar atau cepat. 
i. Jumlah kelompok yang terlalu banyak

Sistem yang digunakan SDIT Ukhuwah Banjarmasin dalam pembelajaran Al-Qur'an adalah sistem kelompok. Menurut ketentuannya jumlah standar dalam satu kelompok yaitu 1015 orang anak. Sedangkan di SDIT tersebut ada kelompok yang jumlah anaknya melebihi standar yaitu 16-19 orang anak.

Pengalaman-pengalaman menunjukkan bahwa pengelompokan siswa yang baik adalah: (1) 3 atau 4 orang siswa perkelompok, (2) mencampur siswa putra dan putri (idealnya 2 laki-laki dan 2 perempuan), (3) siswa puta putri duduk berseberangan. Akan tetapi, meskipun sangat disarankan, pengaturan seperti di atas bukanlah suatu keharusan. Bahkan, biasanya jumlah siswa dan siswi dalam suatu kelas tidaklah sebanding. Guru harus dapat memutuskan pembentukan kelompok berdasarkan kondisi dan karekteristik kelas.

\section{Metode/cara guru Al-Qur'an dalam mengatasi kesulitan belajar membaca Al-Qur'an}

Dari hasil pengamatan dan wawancara dengan kepala sekolah, waka kurikulum, dan bapak/ ibu guru Al-Qur'an di SDIT Ukhuwah Banjarmasin peneliti dapat mengetahui metode guru Al-Qur'an dalam mengatasi kesulitan belajar membaca Al-Qur'an pada siswa kelas III sebagai berikut:

Guru Al-Quran dalam menghadapi perbedaan karakter kelompok atau siswa yang sebagian ada yang kemampuannya tinggi dan ada juga yang kemampuannya rendah perlu menggunakan metode yang tepat untuk mengatasi kesulitan belajar yang mereka alami. Seorang guru harus mampu melihat kondisi siswa yang sebenarnya sehingga tidak salah dalam menggunakan sebuah metode. Metode merupakan jalan atau cara yang harus ditempuh untukmencapai tujuan, walaupun diketahui bahwa setiap metode itu ada kelebihan dan kekurangannya.

Dari kesulitan-kesulitan belajar siswa kelas III tersebut, guru-guru Al-Qur'an SDIT Ukhuwah Banjarmasin berupaya mengatasi kesulitan-kesulitan tersebut dengan menggunakan metode Ummi. Karena metode ummi ini memiliki variasi metode yang dapat digunakan dalam proses pembelajaran. Dengan variatif tersebut menjadikan pembelajaran lebih mudah, menyenangkan dan menyentuh hati anak serta dapat menutupi kekurangan-kekurangan yang ada dalam metode tersebut.

Penggunaan variatif medote dalam Ummi tersebut karena pada dasarnya pendidikan agama dalam hal membaca Al-Qur'an tidak akan berhasil apabila hanya menerapkan saru metode saja. Setiap metode memiliki keunggulan dan kelemahan masing-masing.

Metode ceramah misalnya hanya tepat digunakan ketika guru hendak mengajarkan faktafakta baru, akan tetapi jika dalam membaca Al-Qur'an menggunakan metode ceramah saja tanpa adanya praktik tentu dalam proses pembelajaran tidak akan membuat siswa tersebut tertarik bahkan merasa bosan dan jenuh sehingga perlu adanya berbagai metode yang bervariasi.

Metode Ummi memiliki variasi metode yang mengacu pada teori gaya belajar, yakni visual, auditori, dan kinestetik. Gaya belajar visual diterapkan pada saat siswa memperhatikan tulisan pada alat peraga atau buku. Gaya belajar auditori diterapkan pada saat siswa mendengarkan bacaan guru dengan Teknik 1 (guru membaca siswa mendengar). Sedangkan gaya belajar kinestetik diterapkan pada saat siswa menunjuk tulisan yang sedang dibaca pada buku. 
Keunikan metode belajar Al Quran ini adalah siswa diajak untuk mempraktikkan gaya belajar ini secara bersamaan. Terutama gaya belajar visual dan auditori. Hal ini karena metode belajar Al Quran bersifat praktis. Siswa dapat mencapai kompetensi jika menerapkan gaya belajar melihat tulisan, mendengar bacaan, menunjuk, dan yang lebih penting dari tiga gaya belajar ini adalah gaya belajar dengan lisan atau verbal. Gaya belajar lisan adalah gaya belajar inti yang harus diterapkan dalam semua bagian dari proses belajar Al Quran sebagaimana yang diterapkan oleh Rosululloh dan para sahabat beliau.

Variasi metode Ummi dalam proses belajar Al Quran sebagai berikut:

1. Membuat kelompok sesuai kemampuan dan tingkat siswa

Dalam kelas kemampuan anak-anak sangat beragam, ada yang cepat, sedang, dan ada yang lambat. Maka dengan sistem kelompok guru-guru bisa mengelompokkan mereka sesuai kemampuan dan tingkatan mereka masing-masing. Sehingga anak akan mudah belajar bersama-sama dengan anak-anak yang lain dan dapat mengikuti pelajaran guru secara bersamaan. Dengan sistem kelompok siswa yang kurang paham dapat belajar lebih baik dengan bantuan siswa yang cepat menangkap pelajaran. Begitu pula siswa yang cepat menangkap pelajaran dapat memperdalam pemahaman dengan memberi penjelasan atas suatu subjek pada siswa yang kurang paham dan juga siswa akan dapat membangun hubungan yang lebih baik dengan satu sama lain.

2. Menggunakan buku pada saat klasikal peraga

Siswa dengan gaya belajar visual membutuhkan visualisasi tulisan yang jelas dan terjangkau. Maka guru dapat memberikan toleransi bagi siswa dengan gaya belajar visual untuk melihat tulisan di buku pada saat klasikal. Ini akan mempermudah siswa untuk mengakses tulisan dengan baik, jika visualisasi pada alat peraga kurang memadai. Langkah ini juga bisa diterapkan untuk siswa yang kesulitan membaca dengan alat peraga karena faktor tulisan kecil atau jauh.

3. Pengulangan

Siswa dengan gaya belajar auditori membutuhkan suara bacaan yang jelas dan terjangkau. Maka guru dapat melakukan pengulangan-pengulangan pada Teknik 1 (guru membaca dan siswa mendengarkan) jika membaca kalimat-kalimat yang panjang dan kompleks, dengan catatan tetap memperhatikan manajemen waktu. Pengulangan dapat dilakukan oleh guru atau oleh siswa yang menguasai bacaan dengan baik untuk memotivasi siswa yang lain. Pengulangan juga berfungsi untuk membantu siswa memahami konsep yang sedang dipelajari.

Begitu pula dengan muroja'ah yaitu mengulang kembali hafalan ayat atau surah yang sudah dihafal dan juga mengulang kembali konsep-konsep yang sudah dipelajari. Dengan pengulangan itu, anak yang tadinya tidak jelas dalam pendengaran atau pemahamnnya akan menjadi jelas. Dan anak yang tadinya lupa atau yang kurang ingat akan kembali ingat dan jika diulang-ulang terus maka anak akan mudah ingat, terbiasa dan hafal.

4. Pelibatan siswa

Siswa dengan gaya belajar kinestetik membutuhkan banyak gerak dalam belajar. Guru dapat mengatasinya dengan melibatkan siswa dalam penggunaan alat peraga. Mintalah 
salah satu siswa untuk maju ke depan dan menunjuk tulisan pada alat peraga pada saat klasikal dengan Teknik 1 (guru membaca siswa mendengar) dan Teknik 2 (guru mendengar siswa membaca). Pelibatan siswa ini dapat dilakukan secara bergantian terutama pada siswa yang cenderung moving atau banyak gerak. Cara ini juga dapat diterapkan untuk mengatasi anak yang mengalami kesulitan dalam memusatkan perhatian pada saat klasikal.

5. Penggabungan metode klasikal baca simak atau klasikal baca simak murni

Pada kondisi tertentu dimana siswa menghadapi konsep bacaan yang sulit, kalimat yang kompleks dan panjang, siswa mengalami kebosanan atau kelelahan sehingga hilang konsentrasi. Kondisi ini dapat diatasi dengan menggabungkan metode klasikal dan metode baca simak. Jika pada saat menerapkan metode baca simak dengan buku banyak siswa yang mengalami kesulitan membaca, tersendat, dan hilang konsentrasi, maka guru segera mengambil langkah. Caranya dengan kembali memusatkan perhatian siswa pada alat peraga. Tujuannya adalah untuk lebih memahamkan konsep, dan mengetahui dimana letak kesulitan yang dialami.

Penggabungan klasikal peraga dengan baca simak yaitu siswa membaca kalimat, siswa yang lain mendengarkan, kemudian jika ada kesalahan dikoreksi, lakukan pengulangan konsep secara singkat. Kemudian guru dan siswa membaca bersama-sama kalimat tersebut. Siswa kedua membaca kalimat berikutnya, siswa yang lain mendengarkan, kemudian guru dan siswa membaca bersama-sama kalimat tersebut, dan seterusnya sampai semua kalimat di halaman peraga terbaca.

6. Drill (latihan keterampilan)

Dengan adanya latihan keterampilan (drii) maka bahan pelajaran atau konsep yang diberikan dalam suasana yang sungguh-sungguh akan lebih kokoh tertanam dalam daya ingat siswa, karena seluruh pikiran, perasaan, kemauan dikonsentrasikan pada pelajaran yang dilatihkan. Anak didik juga akan dapat mempergunakan daya pikirnya dengan bertambah baik, karena dengan pengajaran yang baik maka anak didik akan menjadi lebih teratur, teliti dan mendorong daya ingatnya. Serta adanya pengawasan, bimbingan dan koreksi yang segera dan langsung dari guru, memungkinkan siswa untuk melakukan perbaikan kesalahan saat itu juga. Hal ini dapat menghemat waktu belajar di samping itu juga siswa langsung mengetahui prestasinya.

7. Mengatasi siswa yang memerlukan penanganan khusus

Beberapa siswa mungkin memerlukan metode yang berbeda dengan siswa yang lain. Siswa yang kemampuannya di bawah standar atau pemahamannya yang lambat akan dikelompokkan menjadi satu dengan jumlah yang tidak banyak sekitar 3-6 orang siswa. Dengan menggunakan metode privat individual yakni guru mengajari satu orang anak satu persatu secara bergantian atau dengan kata lain berhadapan berdua-duan antara guru dan siswa. Dengan begitu guru dengan mudah dan maksimal untuk mengajari anak karena mempunyai waktu yang lebih banyak untuk menjelaskan dan memberi pemahaman kepada anak. Guru juga mudah melihat dan menilai kualitas bacaan anak bagaimana perkembangannya. Dan bagi anak yang mampu bisa dipercepat lagi pembelajaran supaya dapat mencapai target. 
Selain itu juga, tahapan yang baik dan benar, target yang jelas dan terukur serta waktu yang memadai akan membuat pengelolaan kelas dan pembelajaran yang efektif mudah bagi guru. Metode Ummi yang digunakan guru Al-Qur'an dibangun dengan bekal kreasi dan keterampilan di antaranya:

a. Kemampuan melakukan precondition, memberikan apersepsi, memecah kebuntuan dan memusatkan perhatian siswa

b. Kemampuan menumbuhkan minat pada siswa, memotivasi, memberikan semangat, dan membangun kepercayaan diri siswa.

c. Menciptakan suasana yang menyenangkan tetapi tetap tegas dan memudahkan siswa dalam belajar

d. Memberikan contoh kepada siswa bagaimana cara belajar visual, auditori, verbal dan kinestetik yang baik. Pada saat salah satu siswa maju untuk menunjuk alat peraga, guru bergabung dengan siswa dalam kelompok. Guru memberikan contoh bagaimana memusatkan perhatian ke tulisan pada alat peraga, bagaimana mendengarkan dengan konsentrasi, mengikuti membaca dengan suara jelas, dan membaca dengan benar dan kompak.

e. Mendorong partisipasi siswa dalam setiap proses pembelajaran, mulai dari memimpin doa, klasikal alat peraga, baca simak buku, muraja'ah dan hafalan. Siswa diajak untuk aktif, berperan serta dan melatih kemampuan verbal siswa.

\section{Penutup}

Dari penelitian yang dilakukan peneliti dengan judul "Upaya Guru Al-Qur'an Dalam Mengatasi Kesulitan Belajar Membaca Al-Qur'an di SDIT Ukhuwah Banjarmasin”. Berdasarkan data yang diperoleh dari observasi, wawancara serta dokumentasi dapat disimpulkan sebagai berikut:

1. Kesulitan-kesulitan siswa kelas III dalam belajar membaca Al-Qur'an di SDIT Ukhuwah Banjarmasin yaitu: siswa sulit konsentrasi atau memusatkan perhatian ketika belajar, siswa sangat aktif secara verbal, siswa lambat belajar, siswa suara pelan, siswa susah melihat, siswa aktif bergerak, siswa pasif, siswa yang kemampuannya rendah sulit belajar bersama dengan anak yang kemampuannya standar atau di atas rata-rata, dan jumlah anak di dalam kelompok yang terlalu banyak melebihi jumlah standar kelompok.

2. Metode yang digunakan guru Al-Qur'an dalam mengatasi kesulitan belajar membaca AlQur'an pada siswa kelas III yaitu: metode Ummi karena metode ini memiliki metode variatif yang bisa digunakan untuk mengatasi kesulian belajar pada anak, seperti pengelompokan kelas, menggunakan buku pada saat klasikal peraga, pengulangan dan muraja'ah, pelibatan siswa, penggabungan metode klasikal baca simak atau klasikal baca simak murni, drill (latihan keterampilan) dan mengatasi siswa yang memerlukan penanganan khusus.

\section{DAFTAR PUSTAKA}

Arikunto, Suharsimi. (2006). Prosedur penelitian suatu pendekatan praktik. Jakarta: Rineka Putra As-Syilasyabi, Abu Yahya. (2007). Cara Mudah Membaca Al-Qur'an Sesuai Kaidah Tajwid. Yogyakarta: Daar Ibn Hazm 
As-Suyuthi, Jam'ul Jawami' aw al-Jami'ul Kabir, (tp.), bab huruf hamzah, juz 1, hadits ke-924.

Daradjat, Zakiah. (1996). Ilmu Pendidikan Islam. Jakarta: Bumi Aksara.

Depag RI. (1997). Metode-metode Membaca Al-Qur'an di Sekolah Umum. Jakarta: Dirjen Pembinaan Kelembagaan Agama Islam

Hadi, Sutrisno. (2004). Metodologi Reseach Jilid 2. Jogjakarta: Andi Offset.

Indriana, Dina. (2011). Mengenal Ragam Gaya Pembelajaran Efektif. Jogjakarta: DIVA Press

Maidir, Harun, dkk. (2007). Kemampuan Baca Tulis Al-Qur'an Siswa SMA. Jakarta: DEPAG Badan Litbang dan Puslitbang

Moleong, Lexy J., (2002). Metodologi Penelitian Kualitatif. Bandung: Rosda Karya

Narbuko, Cholid dan Abu Ahmadi. (2005). Metodologi Penelitian. Jakarta: Bumi Aksara

Nasih, Ahmad Munjin dan Lilik Nur Kholidah. (2009). Metode dan Teknik Pembelajaran Pendidikan Agama Islam. Bandung: Refika Aditama

Syarifuddin, Ahmad. (2004). Mendidik Anak Membaca, Menulis, dan Mencintai Al-Qur'an. Jakarta: Gema Insani Press 